\title{
Sui Generis Geographical Indications for the Protection of Non-Agricultural Products in the EU: Can the Quality Schemes Fulfil the Task?
}

\author{
Andrea Zappalaglio • Flavia Guerrieri · Suelen Carls
}

Published online: 3 December 2019

(C) The Author(s) 2019

\begin{abstract}
This paper analyses the suitability of the extension of the EU quality schemes - Protected Designations of Origin (PDOs) and Protected Geographical Indications (PGIs) - to the protection of non-agricultural products. In particular, the work develops an original investigation on the nature of these goods and assesses whether it is compatible with the scope of protection of the EU sui generis GI system, which is determined by the different origin link that characterises the two abovementioned quality schemes. The research, by applying a mixed comparative/ empirical methodology and building upon a previously unpublished dataset, develops an analysis divided into three parts, reaching the following conclusions. First, if sui generis GIs were chosen as the means to protect non-agricultural products, the French legislation on the sui generis protection of handcrafts should be
\end{abstract}

\footnotetext{
This article has been developed within the context of the work of the Max Planck GI Research Team and is the result of the joint effort of the authors. In particular, Andrea Zappalaglio completed the following Sects: 1, 2, 3, 4, 5.2, 6, 7, 8; Flavia Guerrieri completed Sects. 4.1 and 4.3; Suelen Carls completed Sect. 4.2; Sect. 4.4 was developed jointly by Zappalaglio and Guerrieri; Sects. 5.1, 5.3, 5.4 were developed jointly by Zappalaglio and Carls.
}

\footnotetext{
A. Zappalaglio $(\square)$

DPhil (University of Oxford, UK), LL.M. (University College of London); Senior Research Fellow and Project Leader, Max Planck Institute for Innovation and Competition, Munich, Germany e-mail: andrea.zappalaglio@ip.mpg.de

F. Guerrieri

Ph.D. Candidate (Vrije Universiteit, Amsterdam, The Netherlands); Junior Research Fellow, Max Planck Institute for Innovation and Competition, Munich, Germany

e-mail: flavia.guerrieri@ip.mpg.de

S. Carls

Ph.D. (Federal University of Santa Catarina State, Brazil and University of Oxford, UK); Senior Research Fellow, Max Planck Institute for Innovation and Competition, Munich, Germany e-mail: suelen.carls@ip.mpg.de
} 
considered as the best practice. Second, the empirical analysis shows that, since non-agricultural goods are characterised by a loose link to a specific place, predominantly based on the on the product's history and on its distinctive traditional method of production, PGIs seem to be fit for the purpose. Indeed, the analysis of a sample of non-terroir agricultural products protected by PGIs will highlight this parallelism. Third, evidence shows that PDOs could be useful only in a small number of cases while the rationale of Traditional Specialities Guaranteed (TSGs), despite not being origin labels, can be useful to define products that cannot be linked to a specific area by physical or natural elements. Therefore, the EU legislator should take these elements into consideration if it decides to extend the EU GI regime to non-agricultural products.

Keywords EU GI Law · Protected designation of origin · Protected geographical indications · Non-agricultural products · Handcrafts · Regulation 1151/2012

\section{Introduction}

This article contributes to the assessment of the suitability of extending the existing EU sui generis GI rules, specifically the quality schemes Protected Designations of Origin (hereinafter, PDOs) and Protected Geographical Indications (hereinafter, PGIs), to the protection of non-agricultural products. For the purposes of the present contribution, this category includes all the goods that are currently excluded from protection under EU GI law, such as handcrafts and other non-food products or drinks. ${ }^{1}$ In particular, this work highlights the parallels between non-agricultural GIs protected under the national regimes of three EU countries that represent an extremely relevant share of the registered EU GIs - France, Italy and Portugal and non-terroir GIs registered under Regulation 1151/2012. This article, instead, will not cover other issues that, although relevant, would exceed the scope of the present analysis. These include questions concerning the best institutional framework to be adopted and/or additional policy matters relevant to understanding how an EU system for the protection of non-agricultural GIs should be designed as a whole.

Sui generis GI regimes that protect non-agricultural products are not unprecedented. For instance, India is a famous case of a legal system that protects more handcrafts than foodstuffs and agricultural products. ${ }^{2}$ Moreover, at the international level Art. 22(1) of the TRIPS Agreement extends the possible scope of protection of GI rules to "goods" in general, thus setting no limits on the nature of the assets that can be protected. ${ }^{3}$ In the EU, however, the scope of the sui generis GI system is still limited to agricultural products and foodstuffs, falling under the scope of Regulation

\footnotetext{
${ }^{1}$ For an overview of the EU provisions of sui generis GIs, see Blakeney (2014) and Mantrov (2014).

2 The case of India will not be discussed in this paper. For more information, see Marie-Vivien (2015) and Das (2010), p. 148.

3 Art. 22(1) TRIPS reads as follows "Geographical indications are [...] indications which identify a good as originating in the territory of a Member, or a region or locality in that territory, where a given quality, reputation or other characteristic of the good is essentially attributable to its geographical origin."
} 
$1151 / 2012^{4}$ : wines, spirits and aromatised wines. This is due to the fact that the rationale of this regime is still largely based on the traditional French approach that protected wines and niche foodstuffs such as cheese. ${ }^{5}$ This translated, after an evolution that cannot be presented here, ${ }^{6}$ into the EU sui generis system whose scope of protection often, although not always, encompasses goods that are linked to their area of origin by a physical element. ${ }^{7}$ By contrast, as observed by MarieVivien:

While natural factors besides the soil, such as the climate, the origin of raw materials, or environmental elements, can indeed influence product quality for some handicraft products, the territorial link for non-agricultural products or handicraft goods is based above all on the producers' know-how, skills and practices - that is, on human factors. ${ }^{8}$

Because of these historical and theoretical reasons, the EU GI regime has never been extended to non-agricultural products. As a consequence, these goods are protected at the national level by each Member State independently through a variety of legal instruments, as the field is still lacking harmonisation. ${ }^{9}$

However, since 2011 EU institutions have begun to take into consideration the introduction of a sui generis system for the protection of indications of geographical origin for non-agricultural products. ${ }^{10}$ Then, on 18 February 2013, InSight Consulting, REDD and OriGin published the important "Study on geographical indications protection for non-agricultural products in the internal market". ${ }^{11}$ This complex work conducted, among the other things, an empirical survey of this sector and a comprehensive review of the national laws in force during that period in order to outline a possible structure for a sui generis legal frame for the protection of nonagricultural products. $^{12}$

This was followed in 2014 by a Green Paper aimed at gathering the points of view of relevant stakeholders. ${ }^{13}$ The results of this initiative were published by the

\footnotetext{
${ }^{4}$ Regulation (EU) No 1151/2012 of the European Parliament and of the Council of 21 November 2012 on quality schemes for agricultural products and foodstuffs.

5 For a recount of the French experience, see Gangjee (2012), pp. 96-114, Marie-Vivien (2012) and Le Goffic (2010). See also, Zappalaglio (2018).

${ }^{6}$ One of the best references on this topic is still, Gangjee supra note 5, pp. 223-237. See also, Zappalaglio supra note5.

7 For a comparative discussion on the use of natural factors as a linking element, see Marie-Vivien, supra note 4, pp. 87-97.

8 See Marie-Vivien (2016), p. 295. See also, Delphine Marie-Vivien (2013b), p. 191; and Marie-Vivien supra note 2, pp. 70-87.

9 For an overview of the different instruments that protect this class of products, see InSight, REDD, OriGin (2013), pp. 29-33.

10 The document that started the debate on this point was the Communication published by the EU Commission entitled “A Single Market for Intellectual Property Rights". See, EU Commission (2011).

11 InSight, REDD, OriGin supra note 9.

12 In its conclusions, the report, among the other things, suggested a system providing protection to GIs only, thus excluding the AOs and recommended the introduction of a specific register for non-agricultural GI names, with a one-step registration procedure at the EU level. Ibid, p. 328.

13 EU Commission (2014).
} 
Commission in 2015 in a document entitled "Results of the public consultation and public conference on the Green Paper". ${ }^{14}$ The outcomes of this document will be taken into account by this work, since the stakeholders stressed a number of relevant points. In particular, among the other things: (a) they highlighted the importance of ensuring that the origin link is reliable and carefully assessed; (b) they stressed the fact that only a system based on registered GIs can provide the necessary legal certainty and ensure the effective enforcement of rights; and (c) they agreed on the fact that the system should be based on the model of EU sui generis GIs with the necessary improvements. ${ }^{15}$

On 6 October 2015 the EU Parliament approved a resolution "on the possible extension of geographical indication protection of the European Union to nonagricultural products" (hereinafter, the Resolution). In this document, this EU institution discusses, among other things, the ways in which the protection of geographical names for non-agricultural products in Europe should be structured and proposes some guidelines. First of all, despite acknowledging that different protection regimes may be available, the Parliament explicitly mentions an extension of the EU sui generis GI system. In particular, it refers specifically to the outcomes of the 2014 Consultation that were favourable to that solution, ${ }^{16}$ as well as to the strong trust of its members in the instrument. ${ }^{17}$ Next, the Parliament, discusses the general criteria on which this extension should be based. In particular, it argues that the proposed GI regime for non-agricultural products should be based (a) on the best practices and (b) on the experience gained in the agricultural and food sector. ${ }^{18}$

Finally, after these two years of intense discussions, the debate was unable to make meaningful progress and the Commission has never put forward a specific proposal on this matter. However, recently the interest surrounding this issue has revived. In particular, in October 2018 the DG Internal Market of the EU Commission launched a "Study on the economic aspects of sui generis GI protection for non-agricultural products in Europe". 19

This article aims at contributing to the debate from a legal perspective. Although different instruments are available to protect the indications of geographical origin for products of this kind, such as trade mark or unfair competition law, this work will focus specifically on the EU sui generis GI rules and, in particular, on the set of rules provided by Regulation 1151/2012 for the protection of agricultural products and foodstuffs. ${ }^{20}$ There are at least two reasons that justify this choice. First, the few laws on the sui generis protection of geographical names for non-agricultural products that already exist at the national level are, generally speaking, inspired by

\footnotetext{
14 EU Commission (2015).

15 Ibid, p. 4. In February 2015, also the European Economic and Social Committee submitted a positive opinion on the project. See, EESC (2014).

16 See para. 1.

17 See paras. 5 and 33.

18 See paras. $34-35$.

19 Gangjee 2017a.

20 Supra note 4.
} 
the EU GI system. This is exactly the case of the French Loi $n^{\circ} 2014-344$ of 17 March 2014, that constitutes the most relevant set of sui generis provisions currently existing in the EU, as will be shown in due course. ${ }^{21}$ Second, because, as shown above, the use of GIs has been positively taken into consideration by both the relevant stakeholders and the EU institutions on more than one occasion.

This paper will assess whether the existing EU quality schemes are compatible with the nature of non-agricultural products. It will do so by carrying out an analysis divided into three parts that apply a mixed comparative/empirical methodology. More specifically, Part 1, under Sect. 4, carries out a comparative review of the legislative provisions on the protection of non-agricultural goods of Italy, France and Portugal; Part 2, under Sect. 5, analyses the specifications of the products protected, either through GIs and collective trade marks, in the three abovementioned countries; Part 3, under Sect. 6, finally, focuses on the features of a sample of non-terroir agricultural products that appear on the EU GI register, in order to assess whether a parallelism with the results of the first two phases can be established. It will be concluded that while PDOs could be useful only in a limited number of cases, PGIs could be effectively employed. Furthermore, it will be observed that the latter quality scheme absorbs many of the functions that constitute the rationale of Traditional Specialities Guaranteed (hereinafter, TSGs). Therefore, PGIs could represent the solution for the numerous non-agricultural products whose identity is mainly based on the adherence to a traditional production method, rather than on reputational elements such as history.

\section{The Toolbox: the EU Sui Generis GI System for the Protection of Agricultural Products and Foodstuffs}

As stated in the Introduction, the present paper will focus on the quality schemes provided by Regulation 1151/2012: these are PDOs and PGIs. Article 5(1) of this legal text defines PDOs as follows:

For the purpose of this Regulation, "designation of origin" is a name which identifies a product:

(a) originating in a specific place, region or, in exceptional cases, a country;

(b) whose quality or characteristics are essentially or exclusively due to a particular geographical environment with its inherent natural and human factors; and.

(c) the production steps of which all take place in the defined geographical area.

This quality scheme is characterised by two main features: first, the link between the product and the place consists in the essential or exclusive relationship between a product and its place of origin due to the specificities of the local environment and/ or other natural characteristics, and to the local know-how, i.e. the human factor.

${ }^{21}$ Infra Sect. 5.1. 
This combination of physical and human elements is known as terroir. ${ }^{22}$ Second, the good must be produced exclusively inside the designated area.

At first sight, these two features do not make this quality scheme particularly suitable for the protection of non-agricultural product. Indeed, as stated above, ${ }^{23}$ handcrafts and non-food goods in general are non-terroir products, i.e. they are not linked to their area of origin through a physical link. However, stating that origin labels like PDOs cannot protect non-agricultural products would not be accurate. Indeed, Appellation of Origin (hereinafter, AO), i.e. an origin label that constitutes a historical predecessor of the latter and similar in terms of legal discipline, ${ }^{24}$ is actually used to protect this kind of goods. In particular, the "Lisbon Agreement for the Protection of Appellations of Origin and their International Registration" (hereinafter, "Lisbon Agreement"), ${ }^{25}$ features an ad hoc register that includes to date 129 AOs for non-food products.

Therefore, the PDO quality scheme can be used, at least in principle, to protect non-terroir products. This generally happens since the products are closely linked to the area of origin, for instance because of the locality and the peculiarities of the raw materials. $^{26}$

The second quality scheme are PGIs. Article 5(2) of Regulation 1151/2012 defines this in the following way:

[...] a name which identifies a product:

(a) originating in a specific place, region or country;

(b) whose given quality, reputation or other characteristic is essentially attributable to its geographical origin; and

(c) at least one of the production steps of which takes place in the defined geographical area.

PGI rules are significantly less demanding than PDOs. First of all, as stipulated by letter (c), only one step of the production must be completed in the designated area. Moreover, the origin link is more flexible and includes "quality, reputation and any other characteristic essentially attributable to the place of origin of the good". In summary, leaving aside the residual "other" type of link, the qualitative element consists in both the natural and human element of the terroir link, while the reputational element is broader and includes some non-physical elements that prove, nonetheless, that the product comes from the identified designated area. In

\footnotetext{
22 An in-depth description of the concept of terroir would exceed the scope of the present paper. For more information on this essential principle, see Gangjee 2017a. Bérard (2016), Barham (2016), Parker (2015) and Wilson (2012), Trubek (2008). See also Zappalaglio supra note 5, Chapter 1.

23 See supra note 8.

24 Art 2(1)(i) of the Geneva Act of the Lisbon Agreement on Appellations of Origin and Geographical Indications (LI/DC/19, 20 May 2015) defines AOs as follows: “'appellation of origin' means the geographical denomination of a country, region, or locality, which serves to designate a product originating therein, the quality or characteristics of which are due exclusively or essentially to the geographical environment, including natural and human factors."

25 The WIPO, Lisbon - The International System of Appellations of Origin, available at https://www. wipo.int/lisbon/en/.

${ }^{26}$ Gangjee, supra note 5, pp. 136, 143.
} 
particular, the reputational element traditionally consisted in the "market reputation", that is the image provided by a good that raises specific expectations in the minds of consumers regarding the characteristics and the origin of a product. ${ }^{27}$ However, the reputational element is also linked to factors that do not merely depend on the consumers' opinions, such as the history of the product and its current social and economic importance. ${ }^{28}$ A shown above, non-agricultural products are a typical example of goods that feature this kind of link.

Indeed, legal concepts similar to that of PGIs already protect handcrafts in some extra-EU jurisdictions. India is a typical example. It has already been shown that this country uses GIs mainly to protect handcrafts. ${ }^{29}$ Indeed, the Indian definition of GIs is close to that of PGIs:

"geographical indication", in relation to goods, means an indication which identifies such goods as agricultural goods, natural goods or manufactured goods as originating, or manufactured in the territory of a country, or a region or locality in that territory, where a given quality, reputation or other characteristic of such goods is essentially attributable to its geographical origin $[\ldots] .{ }^{30}$

It can be noticed that, although the formulation is different, the key elements of this definition are similar to those of PGIs. Therefore, the Indian case shows that a PGI-like system can be applied to non-agricultural products as well.

Finally, it is expedient to mention TSGs. ${ }^{31}$ This is not an origin label and merely certifies that a product has been produced following a specific traditional recipe and/ or with traditional ingredients. This is probably why TSGs are not widely used in practice. However, they are, indeed, relevant for the present analysis as they emphasise the importance of the method of production that is adopted. In fact, there are two ways to register a TSG. The first is that the name of the product must have been traditionally used to refer to the specific product or it must have been used to identify the traditional character or specific character of it. ${ }^{32}$ The second, and more relevant for the purposes of the present article, is the following - a name can be registered as a TSG if the product:

(a) results from a mode of production, processing or composition corresponding to traditional practice for that product or foodstuff; or

(b) is produced from raw materials or ingredients that are those traditionally used. $^{33}$

\footnotetext{
27 See, Gangjee, supra note 5, pp. 225-237.

28 For more information on this specific issue, Gangjee (2017b), pp. 54-59, see also Gangjee, supra note 5, 235-237. See also Zappalaglio supra note 5, pp. 144-146 and Zappalaglio (2019).

29 Supra, note 8.

${ }^{30}$ India, Geographical Indications of goods (registration and protection) Act 1999, No. 48, Art. 2(e).

31 For an analysis of TSGs, see Tosato (2013).

32 Art. 18(2) Regulation 1151/2012.

33 Art. 18(1) Regulation 1151/2012.
} 
This emphasis on the traditional character of the method of production is important for products such as non-agricultural goods, which, being almost always non-terroir related, must almost unavoidably be linked to their area of origin by human factors. ${ }^{34}$ As it will be shown below, ${ }^{35}$ the traditional character of the production method is often one of them and is of primary importance.

Having provided these introductory remarks, it is now necessary to proceed to a description of the methodology that has been adopted and of the materials that have been collected to conduct the analysis.

\section{The Conducted Empirical Research: General Methodology and Structure}

\subsection{Structure: A Three-Part Analysis}

As mentioned in the Introduction, this article will apply two guidelines that were put forward by the EU Parliament: first, to analyse the systems of protection that are currently in place at the national level in the EU; and second, to take into account the experience gained in the agricultural and food sectors in order assess the suitability of an extension to non-food products. ${ }^{36}$

Following these guidelines, the present work will conduct an empirical analysis divided into three distinct parts. Part 1 will investigate the national provisions of some selected countries in order to understand how non-agricultural products are protected by these Member States in the absence of a unitary EU framework and whether some common trends can be identified. Part 2 will analyse the specifications of a broad sample of relevant goods, protected both by GIs and collective trade marks (CTMs), in order to extract some recurring trends emerging from these documents and compare them with the findings of Part 1. Part 3 will assess the features of various non-terroir agricultural products retrievable through the official EU GI database to understand whether these goods can constitute a model in case the EU regime is extended to non-agricultural products. The criteria of assessment applied to each part will be described at the beginning of the relevant sections.

\subsection{General Presentation of the Selected Samples and of the Sources Used}

In order to proceed with the development of Part 1 and Part 2 of the analysis, some specific choices had to be made. Indeed, research extending to the legislations of all the EU Member States would have exceed the scope of the present paper, especially because of the broad and inhomogeneous nature of the different national experiences. Hence, first of all, the investigation has focused on three selected

\footnotetext{
34 Marie-Vivien, supra note 8, pp. 303-307.

35 Infra, Table 3.

36 The European Parliament, Resolution of 6 October 2015 on the possible extension of geographical indication protection of the European Union to non-agricultural products, paras. 34-35, available athttp:// www.europarl.europa.eu/doceo/document/TA-8-2015-0331_EN.html.
} 
countries: Portugal, France and Italy. This selection is justified by the fact that Italy and France are the leading EU countries in the field of sui generis GIs; Portugal is another relevant country in this sector and, as it will be shown, has enacted general provisions on the protection of handcrafts through GIs.

Next, two main sets of selected materials have been collected from the legislation of these sample countries. First of all, Part 1 features an analysis of the French and the Portuguese laws on the protection of non-agricultural products through GIs. Second, the work will describe the Italian regulatory system of the handcraft sector that, although not based on GI law, will contribute to outline the complex variety of the solutions adopted at national level by the EU Member States.

Part 2 of the analysis then focuses on the specifications of different goods protected by sui generis GIs or CTMs in the three abovementioned sample countries. In total, 112 specifications have been analysed. These samples are the result of an original and independent research effort that partially draws upon, without limiting itself to, the sources that were mapped in 2013 by the InSight, REDD, OriGin report. In particular, the data were gathered initially through database searches. ${ }^{37}$ However, since the data were not always easily retrievable through this procedure, general online research was conducted as well. ${ }^{38}$ Moreover, some specifications could be found by contacting directly the relevant associations, trade mark owners and GI beneficiaries. ${ }^{39}$

Part 3, finally, is aimed at analysing the specifications of a set of selected registered non-terroir products, in order to assess whether they can constitute a viable model for non-agricultural GIs. Hence, the research has selected as sample the PGIs registered under product class 2.4 of the EU register for names of agri-food products that includes "bread, pastry, cakes, confectionery, biscuits and other baker's wares". As of 31 December 2018, 75 PGIs have been registered in this category, including one from a third-country (Turkey).

\footnotetext{
37 In particular France, which offers information on non-agricultural GIs on the website of the Institut national de la propriété industrielle (INPI), i.e. national authority in charge of industrial property register. Hence, the majority of the French data included in the sample was sourced from there. See, Institut National de la Propriété Industrielle, "Base Indications Géographiques" available at https://www.inpi.fr/ fr/comprendre-la-propriete-intellectuelle/les-indications-geographiques.

38 For example, concerning Italy, no information could be found on the databases of the Patent and Trademark Office (Ufficio Brevetti e Marchi) or on that of the Ministry of Agriculture. Instead, in Portugal, the national authority in charge of industrial property register, the Instituto Nacional da Propriedade Industrial, keeps track of all the registered GIs. However, the specifications are not available on the Institute's website. Hence, with exception of one specification that is embodied in a law, the remaining ones were found on the websites of the specific control bodies or by contacting directly relevant professionals and associations.

${ }^{39}$ We are also thankful to the EU Commission DG Internal Market for some interesting feedback and insights.
} 


\section{Part 1: Comparative Analysis of Legislative Provisions on the Protection of Non-Agricultural Goods}

Part 1 of the analysis will compare and contrast the national provisions of the three selected sample countries: France, Portugal and Italy. These provide an interesting insight into the variety of legal solutions adopted by the individual EU Member States in the absence of a unitary system of protection of non-agricultural goods. In particular, this comparative assessment is aimed at highlighting the common trends that will allow an understanding of how these goods are described and protected in these jurisdictions. These will be later tested against the findings that will be revealed by the next phases of the research.

\subsection{The French Legislation}

\subsubsection{The Origin of the Law}

Before the introduction of the "Law on consumption" (Loi relative à la consommation) No. 2014-344 of 7 March 2014 (hereinafter, "Loi Hamon", from the surname of its promoter), the French system did not envisage any limitations to the classes of products that could enjoy legal protection through appellations of origin. However, the appellations of origin granted to non-agricultural products were very few. This was due to the fact that it was difficult to meet the specific requirements to obtain an $\mathrm{AO}$ - that is, the presence of both human and natural factors. ${ }^{40}$ Therefore, while few products managed to obtain an AO through judicial recognition, ${ }^{41}$ the majority of producers saw their protection rejected because they could not fully comply with the legal requirements. ${ }^{42}$ This French system of geographical indications for industrial and artisanal product is one of the rare examples in the EU of national sui generis GI general law for the protection of nonagricultural products.

The debate at the national level on the need to grant legal protection to nonagricultural products began in 2011, due to the cases involving the "Couteaux de Laguiole" and the "Savon de Marseille", products all characterised by a traditional know-how typical of a specific geographical area. ${ }^{43}$ Those cases involved, respectively, the producers knives in the town of Laguiole and of the soap producers of the city of Marseille taking action to have their ancient reputation recognised and protected against misappropriation. These litigations focused the attention of the French legislator on the need of providing, also at the EU level, a suitable legal protection of non-agricultural products though GIs. ${ }^{44}$ The first bill including GIs for non-agricultural products was presented at the Conseil des Ministres (Council of

\footnotetext{
40 These are the factors provided by the Lisbon Agreement, see supra note 25.

41 For example, some remarkable cases are: "Dentelle de Puy", "Poterie de Vallarius" and "Cholet". See Marie-Vivien, (2013a, b), p. 7, Cordier and Vilar (2013), p. 5 and Bineau (2013), pp. 6-7.

42 See the case of "Faience de Moustiers" as an example in Bineau (2013), supra note 41 pp. 6-7.

43 Marie-Vivien (2013a, b), p. 1.

44 Bineau (2013) supra note 41, p. 12.
} 
Ministers) in 2011. However, the text of the draft law, discussed at the National Assembly, did not lead to concrete results untill 2013, when a new draft was discussed and approved, thus leading to the enactment of Law No. 2014-344. ${ }^{45}$

From the discussion of the Loi Hamon, it is clear that the most important goals to be attained were: (1) to grant higher protection against counterfeiting of products which are well known for their link with the national territory; (2) to convey more transparent information to consumers; and (3) to avoid any risk for the consumer of being misled. ${ }^{46}$

\subsubsection{Structure of the Law}

The law created a new kind of sui generis geographical indication, adding the following provisions to the intellectual property code: Art. L712-2-1 (which contains the definition of the new geographical indication for industrial and artisanal products); Art. L721-2 and Art. L721-3 (on the registration process); Art. L721-4, Art. L721-5 and Art. L721-6 (on the nature of the applicants); Art. L721-7 (on the content of the specifications); Art. L721-8 (on the enforcement of the legal protection); Art. L721-9 (on the control functions); and Art. L721-10 (implementing legislation). The following analysis provides a picture of how the most problematic issues have been dealt with and managed at the national level.

\subsubsection{Definition of GIs for Non-Agricultural Products}

Article L 721-2 of the French intellectual property code defines the GI for nonagricultural products as follows:

the denominations of a geographical area or a specific place that identifies a product, other than agricultural, that originates from the particular geographical area and whose particular characteristics can be essentially attributed to its geographical origin. ${ }^{47}$

Moreover, this rule, evidently modelled on Regulation 1151/2012, states that in order to obtain a geographical indication for non-agricultural products, the conditions of the production or transformation of the product - such as cutting, extraction and fabrication - must be consistent with the specifications (the chaiers de charges) "certified" or "approved" (homologues) by the competent national authority, which is the Institut National de la Propriété Intellectuelle - "INPI". 48

\footnotetext{
45 Cordier and Vilar (2013), p. 6.

46 See the statement of M. Daniel Fasquelle contained in the First Session of the National Assembly (Assemblée Nationale) of 6 December 2012, p. 6227 available at http://www.assemblee-nationale.fr/14/ pdf/cri/2012-2013/20130088.pdf.

47 Translation provided by the Author, for the original text see https://www.legifrance.gouv.fr/ affichCode.do; jsessionid=9BCF6AF398E2D5218E69E3F8DA55B638.tplgfr37s_1?idSectionTA= LEGISCTA000028742898\&cidTexte=LEGITEXT000006069414\&dateTexte=20190227).

48 Different from the geographical indications for agricultural products and foodstuffs, the competence of the "Institut National de l'Origine et de la Qualité" (INAO), the institution in charge for regulating French agricultural products, has been waived. In addition, the decisions concerning the approval of the
} 


\subsubsection{Production Method}

Contrary to Regulation 1151/2012, in this law there is no mention of how many of the production steps must take place in the identified geographical area, since the only mandatory requirement is the compliance of local producers' current practices with the specifications approved by the INPI. ${ }^{49}$ The rule is completed by the provision contained in Art. 721-7 No. 5. According to this rule, the specification should mention if the production or transformation steps, or both, take place in the geographical area. However, the law does not explicitly require that at least one of the production steps (or all of them) must take place in the geographical area. ${ }^{50}$

\subsubsection{Raw Materials}

The law provides no specific rule concerning the origin of raw materials. The only reference to the raw materials could be the "elaboration" step, mentioned in Art. L 721-7 No. 5. The term refers to all the phases that precede the transformation of raw materials and the production. Therefore, it may - or may not - encompass the search of raw materials. The rule is not clear in this regard. However, in compliance with Art. 721-7 No. 5, while in the specification it should be explicitly mentioned whether the "production" or "transformation" steps take place in the geographical area, this rule seems not to apply to the elaboration step. ${ }^{51}$ With reference to this specific issue, and in the absence of any other clarification, it seems that the French legislator's intent was to remain as flexible as possible in defining this last phase of the production process, in order to grant the producers the possibility to register a GI even if it takes place outside the geographical area. ${ }^{52}$ Moreover, this provision is probably justified by the fact that the law is designed to protect a large variety of products.

\subsubsection{Nature of the Link}

Article L 721-2 offers a first description of the nature of the link between the place of origin and this specific category of products as well as of the nature and extension

Footnote 48 continued

specification by the INPI are published in the BOPI (Bulletin officiel de la propriété intellectuelle), and not in the Journal Officiel, i.e. in the Official Journal. Delphine Marie-Vivien supra note 43, p. 2.

49 Art. L 721-2.

50 Translation provided by the Author. For the original text see https://www.legifrance.gouv.fr/ affichCodeArticle.do;jsessionid=81124D11B954B123A7BA0B345D44C5A3.tplgfr42s_1?idArticle= LEGIARTI000031013055\&cidTexte=LEGITEXT000006069414\&dateTexte $=20190401$.

51 It is clear from the black letter of the law that there is no restriction regarding the place where the production step and transformation should occur. Instead, if one (or more) of these steps take place in the geographical area, it should be mentioned in the specifications.

52 Overall, this would confirm that, for non-agricultural products, the geographical origin of raw materials may not always play a fundamental role in determining the specific qualities of the product. Marie-Vivien (2016), pp. 311-326. 
of the geographical area involved. ${ }^{53}$ As for the nature of the link, Art. L 721-2, making clear reference to Art. 5(2) of Regulation 1151/2012, mentions the quality, the reputation and other characteristics as the elements that must be "essentially attributable" to the geographical origin. The law goes further and adds that in addition to the quality, reputation and other characteristics, the products can be linked to the geographical area by virtue of the "traditional know-how" ("savoirfaire traditionnel"). ${ }^{54}$

This reference is interesting. Indeed, the French law is the first and, for now, the only one to acknowledge that the origin link for non-agricultural products and handcrafts can be based also on localised traditional methods of production. This is sensible since these goods are connected to a specific place, primarily by human rather than by natural factors and, consequently, the mere reputational link, in all its forms, is probably not enough. The empirical analysis below will reveal that the method of production is often essential in order to identify the product and distinguish it from its generic and non-localised variants. ${ }^{55}$ Hence, it is submitted that, as far as the interpretation of the origin link is concerned, this provision of the Loi Hamon should be considered a "best practice" as it construes more realistically the nature of the origin link for non-terroir products, thus including non-agricultural goods.

\subsubsection{Applicants}

As in the case of EU sui generis GIs, a private collective body ("organisme de defense et gestion") submits the specifications of one or more products to the INPI. ${ }^{56}$ It is also in charge of pursuing all the necessary modifications, if requested, as well as of performing the controls of compliance with the conditions laid down in the specifications. ${ }^{57}$ The collective body represents all the local producers that acquire its membership and it acts for the defence of their collective rights. More generally, among its functions there is the preservation and enhancement of the value of the local traditions and know-how, as well as of the derived local products. ${ }^{58}$

\subsection{The Portuguese Legislation}

\subsubsection{The Code of Industrial Property}

The Portuguese Industrial Property Code has protected GIs since 1940, the year of the approval of the first so-called Code of Industrial Property. ${ }^{59}$ The Portuguese

\footnotetext{
53 This is completed by Art. L 721-7 Nos. 4 and 5.

54 See Art. 721-7 No. 4 and 5. Here, the law lists also the requirements of the "cahiers des charges" for obtaining the homologation by the INPI.

55 See infra para. 5.

56 See, L 721-4. Cf. Art. 8(1)(a) Regulation 1151/2012.

57 Cordier, Vilar supra note 45, p. 7.

58 See Art. L 721-6.

59 See specially Art. 165-171 of the "Decreto No. 30679, de 24-08-1940" (Diário da República No. 197/1940, Série I, de 10-12-2018) that deals with the regulation of the denominations of origin.
} 
Code, also known as Law Decree (Decreto-Lei) No. 110/2018, ${ }^{60}$ in its last and most updated version details a full sui generis GIs system that is applied to all kind of goods, including non-agricultural products. ${ }^{61}$

In this regard, Art. 299(5) states that the exercising of the rights conferred by the registration of a GI does not depend,

[...] on the importance of the exploitation or on the nature of the products, and therefore, the appellation of origin or the geographical indication may apply to any typical product originating in the locality, region or territory under traditional and customary production conditions, or formally regulated conditions.

Because of these features, the Portuguese system is rather distinct from the French one. Indeed, the latter was introduced to protect specifically non-agricultural GIs, while in the former case, the protection has always been granted to any kind of products. $^{62}$

\subsubsection{The Structure of the Law}

The sui generis GIs system that is introduced by the Code covers a broad scope and presents sections on: general provisions, including definition and proprietorship and regional demarcation (Arts. 299-300); the registration process, ${ }^{63}$ comprising request and grounds for refusal (Arts. 301-302); effects, invalidity, annullability and lapse of registration, covering also duration, register indication and rights conferred by the registration (Arts. 304-309).

In this regard, the following subsections will provide a view of each of those topics presented by the Portuguese Industrial Property Code.

\subsubsection{General Provisions: Definition, Proprietorship, Delimitation of the Area} and Link The act does not provide a definition for non-agricultural GIs, apart from the information found in Art. 299(5), which clarifies that the concepts and rules of the Code of Industrial property apply to all sorts of products and are defined as follows:

1 - An appellation of origin shall be considered to be the name of a region, a specific locality or in exceptional cases a country used to designate or identify the following types of products:

a) products originating from the region, specific locality or country in question;

\footnotetext{
$\overline{60}$ Diário da República No. 237/2018, Série I, de 10-12-2018.

61 See, for example, "Bordado da Madeira", which is registered as an Appellation of Origin since 1989 (Denominação de Origem No. 6, 31/05/1989).

62 This system must not be confused with the Decree law (Decreto Lei) No. 121/2015, which deals primarily with what is called the "National system of qualification and certification of traditional artisanal productions" (SNQCPAT) and was anticipated by a number of previous acts, which dealt with the issue of protection of the artisanal sector.

63 Art. 303 is dedicated to the international process, which it is not the focus of this paper.
} 
b) products the quality or characteristics of which are essentially or exclusively due to the geographical environment, including natural and human factors, and the production, transformation and creation of which are carried out in the designated geographical area.

2 - Denominations of origin may also include certain traditional designations, whether geographical or not, indicating a product which comes from a region or specific locality and which meets the requirements stipulated in subparagraph (b) of the preceding paragraph.

3 - A geographical indication shall be considered to be the name of a region, a specific locality or in exceptional cases a country used to designate or identify the following types of products:

a) products originating from the region, specific locality or country in question;

b) products the reputation, specific quality or other characteristics of which may be attributed to such geographical region and/or the production, transformation and creation of which are carried out in the demarcated geographical area.

Regarding the proprietorship of the GIs registered under the Portuguese system, the Code establishes that:

4 - The denominations of origin and the geographical indications, when registered, constitute common property of the residents in the locality, region or territory, $[\ldots]$ and may be used indistinctly by those in their respective area who exploit any kind of production, when authorised by the holder of the registration. 5 - The exercise of this right does not depend on the importance of the production or on the nature of the products and, consequently, the denomination of origin or the geographical indication may apply to any typical product originating in the locality, region or territory under traditional and customary, or properly regulated conditions. $^{64}$

Concerning the delimitation of the place of production, the code stipulates under Art. 300, that, when a given area, which is the object of a GI request, is not yet formally recognised by law, then it should be so declared by the officially recognised bodies responsible for the respective area and field of production. These shall take into consideration bona fide and established practices, in conjunction with the higher interests of national or regional economy.

\subsubsection{Registration Process The provisions of the code related to GIs do not deal} with the issue of applicants in a special section or article and, differently from French law, there is no concern about that. Article 301 states that the application for the registration of a GI should include:

a) the name of the individual or collective persons or corporate bodies and contact data, no matter if they are of public or private nature, as long as they have capacity to request and acquire the registration;

\footnotetext{
64 In this regard, see Ribeiro de Almeida (2008), pp. 10-15, to whom "the GIs and the DOs are common and collective property of produces and traders of the designated area".
} 
b) the name of the product and the type of GI that request refers to; and,

c) the traditional or written rules of production for use of the GI (cahier des charges or code of practice), as well as the delimited geographical area.

The registration process is made before the National Institute for Industrial Property that also keeps a virtual database where already granted registrations can be found.

\subsubsection{Effects, Invalidity, Annullability and Lapse of Registration Article 304 of} the Code states that GI protection is unlimited in time and is protected by the rules of the Code, as well as supervening special legislation. Aricle 305 grants the permission to use, as long as the protection lasts, the expressions "Denominação de origem registada (DO)" or "Indicação geográfica registada (IG)", as the case may be.

Finally, Art. 306 deals with the rights conferred by the registration, while Art. 307 deals with invalidity, Art. 308 with annullability and Art. 309 with lapse. These different paths that might lead to the extinction of a GI, follow the general rules of the Code.

\subsection{Other Legislative Examples: Italy}

Apart from the French and, in a more limited way, the Portuguese legal framework, the other European countries seem to lack a specifically tailored system of protection of geographical names through GIs for non-agricultural products. In countries such as Italy and Spain, ${ }^{65}$ for example, the economic and cultural value of the handcraft sector is recognised and regulated by broad sets of rules that do not refer to GI law and that use different instruments, such as CTMs, to convey to consumers information on the origin of the products. Among their objectives, these provisions often stipulate to be aimed at fostering local development and social integration in relation with the handcraft sector.

In Italy, the craft sector entails various activities. After the Constitutional reform of 2001, the full exclusive legislative and operational competence has been officially assigned to the regional authorities. In this context, after 2000, each region has systematised the discipline regulating the whole sector through its own consolidated law. For the purposes of this article, it will be necessary to focus only on the provisions referring to artistic and traditional craftsmanship. As stated above, these rules are aimed at giving a general legislative framework of the whole sector. Therefore, for the purpose of our analysis, not all the identified criteria can be applied. Nevertheless, some relevant elements can be detected.

\footnotetext{
65 The Spanish legal framework will not be analysed in this paper. Here, it is enough to comment that, in that country, the legislative competence is assigned to the autonomous communities and provincial governments. Overall 19 laws on crafts can be detected, generally homogeneous in their structure and containing - each of them - a specific definition of "craft" and "craftsman". This is certainly relevant considering the absence of uniform definitions at the EU level and the relevant differences regarding the definition itself of the sector, among the national legislative systems of EU countries. Consortium of the Cr@ftsman Project, "Report on the situation on Craftsmanship in Europe", p. 5 available at http:// projects.ifes.es/pdfs/craft/craft1.pdf. For more information concerning the details of the Spanish law, see, REDD, OriGin, supra note 9, p. 51.
} 


\subsubsection{Definition of "Artistic and Traditional Crafts" and the Raw Materials Used}

It is interesting to note that almost all regional laws, in defining handcrafts, make reference to traditional techniques of production, carried out primarily manually and in one-of-a-kind creations, rooted in the place of origin and considered as the expression of local culture and history. For instance, the regional laws of the "Abruzzo" and "Basilicata" regions state as follows:

Regional authorities protect and promote crafts that present artistic and traditional nature or that have high economic values connected to the nature of the typical materials used, to the processing techniques and to the places of origin. $^{66}$

The laws of the "Lazio", "Puglia", "Toscana" and "Veneto" regions are consistent in stipulating that:

[...] are considered crafts of artistic value the creations of high aesthetic value or inspired by shapes, models, decorations, styles and techniques that constitute the typical elements of historical and cultural heritage, with reference to areas of established and intense artistic production, or qualified by particular innovative creativity and ingenuity.

Moreover, the same four abovementioned laws feature an identical provision according to which:

Traditional productions are considered to be the production activities carried out according to established techniques and methods, handed down in customs and in manual processing rooted in local or regional customs, and take into account the innovations that, more or less profoundly, in the respect of tradition, introduce changes in the choice and in the use of raw materials, as well as in the systems used. ${ }^{67}$ The processes are carried out mainly manually, but the use of specific equipment and the mechanisation of some processing phases is allowed, with the exclusion of mass production processes, and special processes identified by the regional commission. ${ }^{68}$

\footnotetext{
66 Translation provided by the Author. For the original text see Art. 50, L.R. 30 October 2009, No. 23 available at http://www2.consiglio.regione.abruzzo.it/leggi_tv/abruzzo_lr/2009/lr09023.htm\#_ Toc283193264. See also Art. 34, L. R. 12 August 2015, No. 29 available at http://www.consiglio. basilicata.it/consiglionew/site/consiglio/detail.jsp?sec=107173\&otype=1150\&id=2609396\&anno=2015.

${ }^{67}$ It is interesting to remark that this specific definition of handcraft takes into account the relation between tradition and innovation, not precluding their co-existence. The impact of innovation on the traditional methods of production and the consequences of this interaction on the distinctive qualities of the goods concerned is a controversial and complex topic, which is still debated. See, among the others, Allaire, Casabianca, Thévenod-Mottet, (2011).

68 Translation provided by the Author. For the original text see Art. 11 L.R. (Regione Lazio) 17 February 2015, available at http://www.consiglio.regione.lazio.it/consiglio-regionale/?vw=leggiregion alidettaglio\&id=9255\&sv=vigente; Art. 17, L.R. (Regione Puglia) 5 August 2013 No. 24 available at:

http://portale2015.consiglio.puglia.it/documentazione/leges/modulo.aspx?id=12555; Art. 19, L.R. (Regione Toscana) 22 October 2008 No. 53 available at http://www.isfol.it/sistema-documentale/banchedati/normative/archivio/17671; Art. 22 L.R. (Regione Veneto) 8 October 2018 No. 34 available at http:// www.consiglioveneto.it/crvportal/leggi/2018/181r0034.html.
} 
Finally, it should be noted that the abovementioned definitions very often touch upon the nature of raw materials, and in the majority of cases they are defined as "typical" (tipico). The concept of typicality is not per se linked to that of origin. ${ }^{69}$ However, the traditional nature of the raw materials employed contributes to the character of the product as "traditional" as much as the adoption of a traditional method of production. ${ }^{70}$

\subsubsection{Disciplinari di Produzione and Contrassegno}

Regional laws often mandate the drafting of specifications ("Disciplinari di Produzione") that must be approved by regional administrative bodies and describe, among the other things, the specific production techniques that give the product its peculiar characteristics. ${ }^{71}$ Those public bodies, in addition to their monitoring functions, are usually in charge of establishing and allowing the use of specific labels to distinguish the product on the market for its nature, ${ }^{72}$ geographical origin, qualities, and raw materials.

Moreover, regional laws remain very generic in defining the label used to identify the products made according to the same rules and in the same geographical area. In fact, the simple reference to a sign ("contrassegno") ${ }^{73}$ remains in principle open both to the use of CTMs and GIs. In any case, it seems possible to envisage the absence of future obstacles for the use of GIs as tools for the protection of geographical names. ${ }^{74}$

\subsubsection{Collective Bodies and the Official Register of Artisanal Firms}

In some regional laws, local authorities officially recognise producers operating in the sector and organised in collective bodies. ${ }^{75}$ As for the conditions for the formal

\footnotetext{
69 It is not possible here to explore in depth the concept of typicality. For more information on this, see Allaire, Casabianca Thévenod-Mottet, supra note 67, pp. 6-7. See also, Laferté, (2012); Letablier, Nicolas (1994), p. 541.

70 Cf. Art. 18(1)(b) Regulation 1151/2012.

71 To cite some examples: Art. 36 Legge Regionale (Regione Basilicata) 12 Agosto 2015 No. 29 available at http://www.consiglio.basilicata.it/consiglionew/site/consiglio/detail.jsp?sec=107173\&otype= 1150\&id=2609396\&anno=2015; Art. 51 Legge Regionale (Regione Abruzzo) 30 Ottobre 2009 No. 23 available at http://www2.consiglio.regione.abruzzo.it/leggi_tv/abruzzo_lr/2009/lr09023.htm\#_ Toc283193264.

72 Sometimes, the label can refer to handmade food products (e.g. "della panificazione tipica", Art. 10, Legge Regionale Regione Basilicata, 12 August 2015 No. 29). This is to show that in Italy the sector of handcrafts does not necessarily cover the production of non-agricultural, non-food products but also food products produced according to traditional methods of production.

73 This could be roughly translated with "label" or "distinctive sign".

74 The label normally identifies the goods with the following adjectives: "artistico", "tipico", "tradizionale" ("artistic", "typical", "traditional"). It is important to highlight that even though the geographical name has not been chosen by the Italian legislator as the tool to protect local production, the geographical origin plays an important role in determining the attributes of "traditional" and "typical".

75 Often the collective bodies are promoted by the local authorities themselves and by the associations of producers. See, for example Art. 51 Legge Regionale (Regione Abruzzo) 30 October 2009 No. 23.
} 
recognition of these collective bodies, it is explicitly stated that they: (a) should represent a significant percentage of producers located in the designated geographical area; and (b) they should be governed by statutes that allow the admission, without discrimination, of new producers operating in the same sector and according to the specification. ${ }^{76}$ Moreover, it is expressly stated that these collective bodies should dispose of adequate resources and facilities to be able to carry out the assigned tasks.

In other regional laws, the producers operating in the handcraft sector, organised either individually or collectively, are recognised upon registration in a specific register of artisan firms, ${ }^{77}$ provided that the requirements established by the regional laws and related regulations are met. ${ }^{78}$

\subsection{Observations on the Results of Part 1 of the Research}

Part 1 of the analysis was aimed at investigating the legislation of three key countries in the field of EU GI law. In particular, France and Portugal explicitly recall GIs as a tool for the protection of non-agricultural products. Moreover, the Italian provisions on the regulation of the handcraft sector have also been discussed in order to understand how the leading country in the field of sui generis GIs - as it alone represents more than one-fifth of the GIs registered in the EU - deals with this specific class of goods.

First of all, this analysis shows that this IP right is already used for the protection of non-agricultural goods. Therefore, at least on the basis of the collected results, there is no inherent systemic reason that would prevent the adoption of a unitary system based on it. In particular, it is submitted that France should be considered the "best practice". Indeed, as was shown in the section on this country, ${ }^{79}$ the Loi Hamon is the only legislative act in the EU to be explicitly dedicated to the protection of non-agricultural goods through a specific sui generis GI.

It is relevant to note that the protection of geographical names as a distinctive sign is a peculiarity of both the French and Portuguese systems. This is an essential element which is not present in the Italian regional laws, which are more focused on the regulation, preservation and the promotion of the whole handcraft sector in the national economy, remaining less focused on the specific tool used to distinguish the products on the market which, as has been described, is compatible either with CTMs or with GIs.

\footnotetext{
76 See Art. 51 Legge Regionale (Regione Abruzzo) 30 Ottobre 2009 No. 23; Art. 35 Legge Regionale (Regione Basilicata) 12 Agosto 2015, No. 29.

77 See, for example, Art. 15 Legge Regionale (Regione Lazio) 17 Febbraio 2015 No. 3.

78 Sometimes, regional laws are accompanied by regulations that specify their content. Therefore, the sectors covered by the general regional rules on the artisanal and traditional craft sector can be more detailed. For example, Annex A of the Implementing Regulation of the regional law of Regione Lazio identifies many kinds of productions such as: tailored clothing, leather goods, drawing and painting reproduction, wooden objects, common metal and precious metal objects, precious stones objects, embroidery, glass, ceramics and, interestingly, also food.

79 Supra at Sect. 4.1.
} 
Moreover, the fact that the Loi Hamon is modelled on Regulation 1151/2012 is interesting as it suggests how a unitary EU Regulation on this matter may look like. In particular, the French law features a definition of GIs for non-agricultural products that mirrors that of PGIs. In addition, the same law features a relevant innovation, that is the substantive role of the element of traditional know-how (savoir-faire traditionnel). Indeed, the reference to this element is something that all the analysed bodies of law have in common. Only France, however, explicitly considers it as a linking factor. More specifically, the Portuguese law differs from the French law as it does not establish a specific GI framework for non-agricultural products but limits itself to making a direct refence to the general GI rules, based on the EU regime. However, it stipulates that the specifications must rigorously identify the characters of the "traditional artisanal production". 80 The same can be observed in relation to the Italian system which, although structured in a complex decentralised way, highlights the relevance of the traditional character of the method of production as well as of the historical and cultural importance of the product as part of a specific heritage. ${ }^{81}$ Finally, all these legal systems grant the beneficiaries a broad margin of flexibility with regard to different aspects of the production, such as the origin of the raw materials and the organisation of production - many steps of which can take place outside of the designated area. This is in line, however, with the relatively undemanding nature of the PGI quality scheme.

Therefore, it is submitted that the historical/reputational link and the adherence to traditional practices of production can be the two elements on which a unitary sui generis GI system for the protection of non-agricultural products could be based. Indeed, the former is a known and valid origin link, ${ }^{82}$ while the latter, despite not being a linking factor per se, ensures that the GI product truly represents what the local producers identify as part of their local heritage. ${ }^{83}$ It is important for these two elements to be present together as one supports the other. This emerges in particular from countries like Italy that generally protect traditional handcrafts through CTMs and that, in order to ensure the locality of the production, often require that the producers appear on specific registers that demonstrate their connection to a given area, as the data provided below will prove. $^{84}$

\section{Part 2: Analysis of the Specifications of Individual Products Protected Through GIs or CTMs}

Part 2 of the analysis will conduct an empirical assessment of the specifications of a broad selection of non-agricultural products protected in Italy, France and Portugal either through GIs or CTMs. This operation has two main goals: first, understanding

\footnotetext{
80 Supra at Sect. 4.1.6.

81 Supra at Sect. 4.3.1.

82 See Gangjee (2017a) and Bérard and Marchenay (2004).

${ }^{83}$ See, among the others, Marie-Vivien supra note 5, Chapters 3 and 4.

${ }^{84}$ Infra Sect. 5.3.1.
} 
how practically the products are described in the relevant technical documents; second, investigating whether the common traits that have been identified during the comparative analysis carried out in Part 1 of the research emerge also through this different kind of investigation. In particular, we are referring to the nature of the origin link and to the importance of the traditional character of the method of production.

\subsection{Materials and Sources}

As explained from the beginning of the present contribution, a detailed analysis of all the legal means adopted by EU Member States to provide protection to nonagricultural products would have exceeded the scope of the present investigation. This is why this research has focused on the contents of specifications. In the interest of completeness, it is expedient to note that these were embodied into different legal instruments such as:

(1) specific GIs registered under the abovementioned French and Portuguese general legal systems ${ }^{85}$;

(2) product-specific collective marks, mostly Italian, both publicly and privately owned such as "Cremona Liuteria" and "Biella Art of Excellence" ${ }^{86}$;

(3) GI rights introduced for individual goods by specific legislative acts such as laws, decrees, orders and so on depending on the jurisdiction that issued them, such as "Bordado da Madeira";

(4) laws introducing a collective mark for an individual product, such as "Marchio Vetro Artistico Murano" ${ }^{87}$;

(5) umbrella collective marks, i.e. collective marks, generally established by law, that are opened to the protection of different varieties of products "Artesanato dos Açores" for Portugal ${ }^{88}$ or "Artigiani in Liguria for Italy". 89

Overall, this work has analysed a sample of 112 specifications that represents a wide variety of product classes. This is summarised in Tables 1 and 2:

It can be noted that in the sample there is a predominance from Italy. This is due to the fact that this country is particularly active in the protection of pottery and ceramics through collective marks, for which a specific law was introduced. Furthermore, the high number of products belonging to Class 47 can be explained by reminding that the latter encompasses various different kinds of goods such as

\footnotetext{
85 See for France: "Porcelaine de Limoges" (No. d'homologation 1702); "Tapisserie d'Aubusson" (No. d'homologation 1803) and for Portugal: "Viola Braguesa" (Indicação Geográfica No. 534); "Bordado de Castelo Branco” (Indicação Geográfica No. 505).

86 See, Consorzio Liutai Antonio Stradivari Cremona, "Il marchio - il regolamento - la tutela" available at http://www.cremonaviolins.com/il-consorzio/il-marchio-il-regolamento-la-tutela/ and Biella Art of Excellence "Disciplinare" available at http://www.biellatheartofexcellence.com/it.html.

87 The protection of the indication of origin "Vetro Artistico Murano" is regulated by a regional law of Veneto, see Legge Regionale, 23 December 1994.

88 Governo dos Açores, “Artesanato dos Açores” available at http://artesanato.azores.gov.pt.

89 Artigiani in Liguria, "Marchio Artigiani in Liguria" available at http://www.artigianiliguria.it/home. php?info= $1 \&$ idq $=1$.
} 
Table 1 Total number of the specifications analysed

\begin{tabular}{ll}
\hline Country & Number of specifications analysed \\
\hline Portugal & 32 \\
France & 10 \\
Italy & 70 \\
\hline
\end{tabular}

Table 2 Classes of products considered in the analysis

\begin{tabular}{|c|c|c|}
\hline Types of goods & $\begin{array}{l}\text { Nice } \\
\text { classification }\end{array}$ & $\begin{array}{l}\text { Number of } \\
\text { products }\end{array}$ \\
\hline Essential oils, soaps and cosmetics & Class 3 & 3 \\
\hline Hand tools and cutlery & Class 8 & 3 \\
\hline Ships & Class 12 & 1 \\
\hline $\begin{array}{l}\text { Precious stones, metals, jewellery, decorative metal } \\
\text { handcrafts }\end{array}$ & Class 14 & 9 \\
\hline Musical instruments and musical boxes & Class 15 & 5 \\
\hline Works of art & Class 16 & 3 \\
\hline Leather and leather made goods & Class 18 & 2 \\
\hline Stones, marbles, building materials & Class 19 & 6 \\
\hline Furniture of various materials and wooden products & Class 20 & 9 \\
\hline Ceramics, pottery, porcelain, glassware & Class 21 & 47 \\
\hline Canvas and other materials for stuffing & Class 22 & 2 \\
\hline Textiles and thread & Class 23 & 7 \\
\hline Clothes and footwear & Class 25 & 3 \\
\hline Embroidery & Class 26 & 9 \\
\hline Carpets, tapestry, rugs & Class 27 & 4 \\
\hline Toys and decorations & Class 28 & 1 \\
\hline
\end{tabular}

ceramics and porcelain but also items made of glass. However, as will be shown below, the research is able to reveal some clear common trends shared by all the sample countries, regardless of these unbalances.

\subsection{Criteria of Assessment: Peculiarities of Part 2 of the Research and Explanatory Examples}

The present research is based on a variety of sources unavoidably characterised by an inhomogeneous nature. Hence, in order to analyse them in a uniform way, this work has adopted a set of parameters for their assessment. This has been designed on the basis of the elements that compose the structure of the Regulation 1151/2012 as well as of the specifications of agricultural products in the EU. In particular, for this part of the analysis, the tables are divided into five sections.

The first section concerns the nature of the owners, in the case of CTMs, or of the applicants, in the case of GIs. Two specific elements have been investigated: (a) the private or public nature of the subject, in order to understand whether publicly 
funded bodies are already engaged in the protection of non-agricultural products; and (b) whether the owners or applicants must appear in a specific register.

The second section, shows the percentage of the products that must be entirely made in the designated area.

The third section, provides data on the way in which the sourcing of the raw materials is managed. The investigation has applied three sub-parameters, specifically: (a) cases in which information on the origin of the raw materials is not given ("NG" in the tables) or where the specification explicitly leaves the producers free to source them from whenever they prefer; (b) cases in which the raw materials must be sourced from inside the designated area; and (c) cases in which they must be sourced from a specific area outside of the designated area.

The fourth section engages in the description of the origin link, which for the purposes of the present analysis is divided in three parameters: (a) nature, (b) history of the product, and (c) tradition in the production. These can be defined as follows:

(a) Regarding the natural element, the work refers to specifications that establish an essential link between the product and some raw materials that are localised in a place, generally the designated area, and that have specific and distinctive characteristics. The specifications of many products made from stone or marble are typical examples. ${ }^{90}$ However, other kinds of goods present this type of link, such as wooden handcrafts. ${ }^{91}$

(b) The historical link consists in the recount of the history of the product made by the producers in order to prove the intangible link between the former and its specific place of origin. For instance, the regulation of the collective mark "Cremona Liuteria" dedicates a considerable amount of text to the description of the history of the musical instruments of Cremona, of their link with the territory. Then, it describes the method of production and why it represents the tradition handed down from generation to generation. ${ }^{92}$ In the case of "Lenços de Namorados do Minho", the specification links the product to its place of origin making reference to its history and the transformations that it underwent due to cultural and social changes in Portugal. ${ }^{93}$

(c) As to the tradition in the production, many specifications provide a description of the traditional practices associated with a product and mandate that it can be considered traditional only if made by adhering to these codified methods of production handed down from generation to generation in a specific place. ${ }^{94}$

\footnotetext{
90 See, for instance "Disciplinare di Produzione della Pietra Ollare della Valtellina e Valchiavenna", Art. 5. available at http://www.marchiovaltellina.it/sites/default/files/mcg/DisciplinarePietraOllare.pdf.

91 See "Fechaduras de madeira da ilha do Corvo" (Portaria No. 3/2019 de 21 de janeiro de 2019, p. 80).

92 Consorzio Liutai "Antonio Stradivari" Cremona, "Cremona Liuteria - Allegato B", p.7, availableathttp://www.cremonaviolins.com/il-consorzio/il-marchio-il-regolamento-la-tutela/.

93 See, "Lenços de Namorados do Minho" (Indicação Geográfica No. 164, 22/07/2010). For a similar case, see also "Siege de Liffol" (INPI-1601, 02/12/2016).

94 See, for instance, "Tuscia Viterbese: Lavorazioni dell'Artigianato Artistico e Tradizionale - Allegato B” para. 3 available at http://www.tusciawelcome.it/gesFiles/Filez/1521562486K171446.pdf. See also, "Barro Negro de Vilar de Nantes" (Indicação Geográfica No. 146, 02/11/2011) and "Pierre de Bourgogne" (INPI-1801, 29/06/2018).
} 


\subsection{Presentation of the Results}

\subsubsection{Overall Results}

These tables present the overall results of the empirical research focusing on the abovementioned selected set of 112 specifications. In particular Table 3 presents the general figure summing up the outcome of the analysis of both GI and CTM specifications, while Tables 4 and 5 isolate the data on GIs and on CTMs, respectively. The tables concerning each individual sample country will be provided in the next section.

\subsubsection{Individual Sample Countries’ Results}

This subsection presents the findings concerning each of the selected sample countries. In particular, Table 6 describes the data related to France, where only GI goods were considered; Table 7 shows the trends related to Italian CTMs, as sui generis GIs for handcrafts do not exist in that jurisdiction; finally, Tables 8, 9 and 10 introduce the data of Portugal divided into overall, GIs only and CTMs only.

\subsection{Observations on Part 2 of the Analysis}

From the results of the conducted analysis, it is possible to make the following observations. With regard to the nature of the owners of CTMs or of the applicants for GIs, the research reveals that, in a high number of cases (85\% overall), they consist of public bodies or institutions. This is especially true for Italy and Portugal. For instance, in Italy the CTM "Ceramica Artistica e Tradizionale" has been introduced by law and it is granted by the Chambers of Commerce. ${ }^{95}$ In Portugal the CTM "Artesanato dos Açores" has also been created by legislative act and it is granted by the Regional Center for Handicraft Support. ${ }^{96}$ In the more limited samples of France, on the other hand, the figure is not as high. However, in general terms, the fact that public bodies are supporting the protection of origin products in the absence of a unitary system may suggest that a step towards a quasi-public bureaucratic system, ${ }^{97}$ such as that of sui generis GIs, would not be overly complex to achieve.

Moreover, it is relevant to notice that, only in Italy, in the $71 \%$ of cases the producers must enter a specific register to obtain permission to use the mark. This registration is aimed at ensuring that the artisans fulfil different requirements, such as having their workshop in the designated area. Although this system constitutes an additional bureaucratic requirement, it may be useful to ensure that a non-terroir product like a handcraft is effectively made in its traditional place of origin.

\footnotetext{
95 See, Legge 9 Luglio 1990, No. 188 "Tutela della ceramica artistica e tradizionale e della ceramica di qualità" (GU 165, 17-7-1990).

96 See Portaria No. 3/2019 de 21 de janeiro de 2019. (Jornal Oficial Região Autonôma dos Açores, I série, No. 8).

97 Gangjee (2017b), p. 12.
} 
Table 3 Overall results: GI and CTM specifications aggregate

\begin{tabular}{llll}
\hline Parameters & Overall & Numbers & Percentage \\
\hline Owners/applicants & & & \\
$\quad$ Public owner/applicant & 114 & 97 & $85 \%$ \\
$\quad$ Registered? & 114 & 40 & $35 \%$ (only Italy) \\
Production & 114 & 106 & $92.9 \%$ \\
$\quad$ In the area & & & \\
Raw materials & 114 & 88 & $77.1 \%$ \\
$\quad$ Anywhere/NG & 114 & 15 & $13.1 \%$ \\
Local only & 114 & 12 & $10.5 \%$ \\
From specific area & & 16 & $14 \%$ \\
Link & 114 & 71 & $62.2 \%$ \\
$\quad$ Nature & 114 & 101 & $88.5 \%$ \\
Human element & 114 & & $99.1 \%$ \\
$\quad$ Traditional method & & 113 & \\
Delimitation of the area & 114 & & \\
Area explicitly defined & & & \\
\hline
\end{tabular}

Table 4 GI results overall

\begin{tabular}{llcl}
\hline Parameters & Overall & Numbers & Percentage \\
\hline Applicant & 28 & & \\
$\quad$ Public owner & 28 & 14 & $50 \%$ \\
$\quad$ Registered? & & 0 & $0 \%$ \\
Production & 28 & 28 & $100 \%$ \\
$\quad$ In the area & & & \\
Raw materials & 28 & 25 & $89.2 \%$ \\
Anywhere/NG & 28 & 3 & $10.7 \%$ \\
Local only & 28 & 1 & $3.57 \%$ \\
From specific area & & & $32.1 \%$ \\
Link & 28 & 9 & $71.4 \%$ \\
$\quad$ Nature & 28 & 20 & $89.2 \%$ \\
Human element & 28 & & \\
Traditional method & & 28 & $100 \%$ \\
Delimitation of the area & 28 & & \\
Area explicitly defined & & & \\
\hline
\end{tabular}

However, this would be likely redundant in a unitary system as, even today, the local character of the production is preserved, also in the other sample jurisdictions, by providing stringent rules on the place of manufacture.

Indeed, with regard to the locality requirement, i.e. how often the product is manufactured in its designated area of origin, the research reveals that in more than 
Table 5 CTM results overall

\begin{tabular}{llll}
\hline Parameters & Overall & Numbers & Percentage \\
\hline Owner & & 83 & \\
Public owner & 86 & 40 & $96.5 \%$ \\
Registered? & 86 & & $47 \%$ (only Italy) \\
Production & 86 & 78 & $90.6 \%$ \\
In the area & & & \\
Raw materials & 86 & 63 & $73.2 \%$ \\
Anywhere/NG & 86 & 12 & $13.9 \%$ \\
Local only & 86 & 11 & $12.7 \%$ \\
From specific area & & & $8.1 \%$ \\
Link & 86 & 7 & $59.3 \%$ \\
Nature & 86 & 51 & $88.3 \%$ \\
Human element & 86 & 76 & $98.8 \%$ \\
Traditional method & & 85 & \\
Delimitation of the area & 86 & & \\
Area explicitly defined & &
\end{tabular}

Table 6 France: overall results (GI only)

\begin{tabular}{llll}
\hline Parameters & Overall & Numbers & Percentage \\
\hline Owner & 10 & 2 & $20 \%$ \\
Public owner & 10 & 0 & $0 \%$ \\
Registered? & 10 & 10 & $100 \%$ \\
Production & & & $70 \%$ \\
In the area & 10 & 7 & $30 \%$ \\
Raw materials & 10 & 3 & $10 \%$ \\
Anywhere/NG & 10 & 1 & $60 \%$ \\
Local only & & & $80 \%$ \\
From specific area & 10 & 6 & $90 \%$ \\
Link & 10 & 7 & $100 \%$ \\
Nature & 10 & 9 & \\
Human element & & 10 & \\
Traditional method & 10 & & \\
Delimitation of the area & & & \\
Area explicitly defined &
\end{tabular}

the $90 \%$ of cases $(92.9 \%$ overall) the selected products are entirely manufactured in the area. This trend is uniform throughout the sample countries. It is submitted that this is a good practice that preserves the local character of goods that per se are nonterroir related and, therefore, essentially based on a technical know-how that can migrate or being displaced. 
Table 7 Italy: overall results (CTMs only)

\begin{tabular}{llll}
\hline Parameters & Overall & Numbers & Percentage \\
\hline Owner & & & \\
Public owner & 70 & 68 & $97.1 \%$ \\
$\quad$ Registered? & 70 & 40 & $57.1 \%$ \\
Production & & & \\
$\quad$ In the area & 70 & 63 & $90 \%$ \\
Raw materials & & 57 & $81.4 \%$ \\
Anywhere/NG & 70 & 4 & $5.6 \%$ \\
Local only & 70 & 9 & $12.8 \%$ \\
From specific area & 70 & 3 & $4.2 \%$ \\
Link & & 43 & $61.4 \%$ \\
$\quad$ Nature & 70 & 66 & $94.2 \%$ \\
Human element & 70 & & $100 \%$ \\
$\quad$ Traditional method & 70 & 70 & \\
Delimitation of the area & & & \\
Area explicitly defined & 70 & &
\end{tabular}

Table 8 Portugal: overall

\begin{tabular}{llcl}
\hline Parameters & Overall & Numbers & Percentage \\
\hline Owner & 32 & & \\
$\quad$ Public owner & 32 & 0 & $84.3 \%$ \\
$\quad$ Registered? & & & $0 \%$ \\
Production & 32 & 32 & $100 \%$ \\
$\quad$ In the area & & & \\
Raw materials & 32 & 82 & $68.7 \%$ \\
$\quad$ Anywhere/NG & 32 & 2 & $25 \%$ \\
Local & 32 & 7 & $6.25 \%$ \\
From specific area & 32 & 20 & $21.8 \%$ \\
Link & 32 & 25 & $62.5 \%$ \\
$\quad$ Nature & 32 & 32 & $78.1 \%$ \\
Human element & & & $100 \%$ \\
$\quad$ Traditional method & 32 & & \\
Delimitation of the area & & & \\
Area explicitly defined & & &
\end{tabular}

Next, the figures concerning the origin of the raw materials are very interesting. Indeed, the specifications regularly mention the features that these must possess in order to be used in the production. However, overall, in $77.1 \%$ of cases the analysed specifications leave the producers free to source them from whenever they prefer or in many cases no indications are given on this matter. In just $13.1 \%$ cases were the raw materials sourced exclusively from the designated area. 
Table 9 Portugal GIs

\begin{tabular}{llcl}
\hline Parameters & Overall & Numbers & Percentage \\
\hline Owner & 17 & 12 & \\
$\quad$ Public owner & 17 & 0 & $70.5 \%$ \\
$\quad$ Registered? & 17 & & $0 \%$ \\
Production & & 17 & $100 \%$ \\
$\quad$ In the area & 17 & 17 & $100 \%$ \\
Raw materials & 17 & 0 & $0 \%$ \\
Anywhere/NG & 17 & 0 & $0 \%$ \\
Local & & & $17.6 \%$ \\
From specific area & 17 & 3 & $76.4 \%$ \\
Link & 17 & 13 & $88.2 \%$ \\
$\quad$ Nature & 17 & 15 & $100 \%$ \\
Human element & & & \\
$\quad$ Traditional method & 17 & 17 & \\
Delimitation of the area & & & \\
$\quad$ Area explicitly defined & & &
\end{tabular}

In many other cases the provisions regarding the origin of raw materials are, nevertheless, more articulated. For instance, sometimes the specifications state that the products should be made only out of local raw materials, but that materials of different origin are allowed as long as they feature compatible characteristics. Therefore, in these cases the parameter "local raw materials only" has not been used. For instance, the specifications of Italian ceramics often do this. ${ }^{98}$ In other examples this choice is not given and the raw materials must be only local. ${ }^{99}$ In other cases, the specifications provide that the raw materials must not necessarily be sourced from the area of manufacturing but, nevertheless, from a specific area, different or broader than the latter. In this case, the work has used the parameter "specific area". For instance, the specification of "Artigiani in Liguria Disciplinare Lavorazioni Pelle", a mark that distinguishes the products of the artisanal leather-made goods, states that the raw materials should be bought from Italian tanneries in order to ensure the quality of the product. ${ }^{100}$ Instead, in the case of "Monoï de Tahiti" the raw materials must be sourced from specified areas in the Polynesia region. ${ }^{101}$ However, some specifications are even more nuanced. For

\footnotetext{
98 See, for instance, "Disciplinare di Produzione della Ceramica Artistica e Tradizionale di Faenza" available at http://www.buongiornoceramica.it/2017/wp-content/uploads/2017/02/Faenza_disciplinare. pdf.

99 See "Porcelaine de Limoges" (INPI-1702, 01/12/2017). In other cases, the raw materials must be sourced from different locations specifically indicated, both inside and outside the designated area, see, for example, "Viola da Terra" (Portaria No. 3/2019 de 21 de janeiro de 2019, p. 83).

100 "Artigiani in Liguria - Disciplinare Lavorazioni Pelle", Art. 4.2, availableathttp://www. artigianiliguria.it/home.php?info=1\&iddisc $=5575$.

101 See "Décret n 92-340 du 1er avril 1992 relatif à l'appellation d’origine 'Monoï de Tahiti' “, Art. 1.
} 
Table 10 Portugal CTMs

\begin{tabular}{llcl}
\hline Parameters & Overall & Numbers & Percentage \\
\hline Owner & & & \\
$\quad$ Public owner & 15 & 15 & $100 \%$ \\
$\quad$ Registered? & 15 & 0 & $0 \%$ \\
Production & & & $100 \%$ \\
$\quad$ In the area & 15 & 15 & \\
Raw materials & & & $33.3 \%$ \\
$\quad$ Anywhere/NG & 15 & 5 & $53.3 \%$ \\
Local & 15 & 2 & $13.3 \%$ \\
From specific area & 15 & & \\
Link & & 4 & $26.6 \%$ \\
$\quad$ Nature & 15 & 7 & $66.6 \%$ \\
Human element & 15 & 10 & $66.6 \%$ \\
$\quad$ Traditional method & 15 & 15 & $100 \%$ \\
Delimitation of the area & & & \\
$\quad$ Area explicitly defined & 15 & & \\
\hline
\end{tabular}

instance, in some cases the raw materials must be sourced both from the inside and the outside of the designated area. ${ }^{102}$ Therefore, the investigation has revealed a nuanced scenario in which, as shown above, the specifications are often indifferent to the origin of the raw materials $(77.1 \%)$. Nevertheless, in the $13.1 \%$ of cases the producers can or must source them locally or from specific areas $(11.4 \%)$.

The findings concerning the nature of the origin link correspond with those on raw materials. As was explained in detail above, ${ }^{103}$ the present research has distinguished the cases in which such a link is proven through the recount of the historical and cultural relationship between the product and its area of origin ("historical link") and/or those in which the connection is established by the description of a traditional method of production, passed down from generation to generation, that is rooted in an area and that allows to discern the original/traditional products from ordinary ones. Finally, also the physical/natural connection between a good and its area of origin has been considered as a linking factor.

In this case the overall results are in line with the country-specific ones. In particular, the "human element" parameter always exceeds $60 \%$ and the "traditional method" parameter is always either around or above $80 \%$. Finally, the physical/natural factor is present overall in only $14 \%$ of cases. It is, however, relevant in France where it is present in $60 \%$ of specifications. This is inconsistent with the other samples and may be explained by the fact that this country protects different kinds of stones, such as "Granit de Perpignan", ${ }^{104}$ "Granit de

\footnotetext{
102 See for instance, Viola da terra - Artisanato dos Açores (Portaria No. 3/2019 de 21 de janeiro de 2019, p. 83).

${ }^{103}$ Supra at Sect. 5.2.

104 See the Cahier des charges IG Grenat de Perpignan (INPI-1802, 23/11/2018), pp. 11-12.
} 
Bretagne", ${ }^{105}$ and "Pierre de Bourgogne" 106 whose origin is intuitively linked to a specific area as well as non-food products of agricultural origin, such as the essential oil "Monoï de Tahiti" ${ }^{107}$ whose specification resembles that of an appellation of origin.

Then, an interesting figure concerns the predominance of the specifications that establish an origin link by making reference to a specific "traditional method". Indeed, this parameter exceeds the "historical link" by almost 20\%. This is interesting because on the one hand, the reliance on a traditional method of production is one of the criteria to apply for a TSG, hence it is considered legally relevant in the EU. ${ }^{108}$ On the other hand, however, this is not per se an origin link. Therefore, it can complete the latter by ensuring the traditional character of the good, but not replace it in toto.

This trend can be explained by observing that Italian CTMs often make reference to the traditional method of production of the goods without mentioning its history at all. However, this is justified by the fact that these CTMs are club rights that gather groups of producers that are relatively homogeneous in terms of geographical location, employed methods of production and history. Furthermore, as was already mentioned, very often the Italian provisions require these artisans to enter a local register, thus providing proof of the location of the workshop and, therefore, of the origin of the product. This finding confirms that in the case of non-agricultural goods the origin link will almost always depend on the human element, for instance, on how the product is made and on whether it is produced following codified and localised production practices rather than ordinary ones.

Finally, almost the totality of the specifications (99.1\%) delimits, sometimes in a very detailed way, the area in which the product has to be produced in order to be marketed under a given geographical name. Under this perspective, the analysed specifications are not different from those of registered agricultural GIs.

In conclusion, the findings of Part 2 of the present research show the selected non-agricultural products as often characterised by an important public intervention and very often entirely produced in the designated area, except for the origin of the raw materials which is often left to the choice of the producers. Moreover, being non-terroir products, they are generally characterised by a reputational link such as a historical one, or by the reference to localised technical know-how. Finally, the area of production of these goods is almost always clearly specified.

\footnotetext{
$\overline{105}$ See the Cahier des charges Indication Géographique Granit de Bretagne (INPI-1701, 20/01/2017), p. 14.

106 See the Cahier des charges Indication Géographique Pierre de Bourgogne (INPI-1801, 29/06/2018), p. 15.

107 See Décret n 92-340 du 1er avril 1992 relatif à l'appellation d'origine "Monoï de Tahiti", Art. 1.

108 See supra at Sect. 1.
} 


\section{Part 3: Non-terroir Agricultural Products Registered in the EU GI Register}

Part 3 of the present research will be dedicated to the analysis of a selected sample of agricultural products that appear on the EU GI register and that are non-terroir related, i.e. they do not owe their distinctive features to a specific link with their area of origin. Indeed, because of this peculiarity, they can be seen as the closest relatives to non-agricultural products. Hence, this analysis will contribute to the understanding of whether the current EU GI regime already embodies specifications that are compatible with those of non-agricultural products, thus showing whether the system as it is today can be applied to these goods or not.

\subsection{Materials, Sources and Criteria of Assessment}

This part of the research has been carried out by collecting the 75 PGI specifications present on the EU register and belonging to the product class 2.4, which includes "bread, pastry, cakes, confectionery, biscuits and other baker's wares".

With regard to the parameters applied for the assessment, the research has collected the latest version of the single documents of these products and, in order to extract workable findings from the raw data, has focused on three of the elements that were already employed in the analysis of the specifications in Part 2: (1) the origin of the raw materials; (2) how much of the production of the good takes place within the designated area; and (3) the description of the origin link. The criteria concerning the nature of the owners and to the presence of the description of the area of production in the specifications have not been applied in this case as they are not relevant. ${ }^{109}$

\subsection{Presentation of the Results}

The results of Part 3 of the research are summarised in Table 11:

It is possible to observe that, as to the locality requirement, 61 specifications out of $75(81.3 \%)$ state that the whole production procedures must take place in the designated area. Only 4 allow for parts of the production to take place outside the designated area, although some of them, at least 10, are unclear on this point, thus providing flexibility to the producer. This figure, however, is probably not extremely relevant because of the nature of the products considered.

With regard to the origin of the raw materials, only 7 specifications (approx. $9.3 \%$ ) explicitly require the raw materials to be sourced locally. In particular, 4 mention local water as an essential requirement. In general, it is interesting to observe that the single documents almost never make prescriptions about where they must be sourced with only rare exceptions. ${ }^{110}$ This indicates that, for this class of non-terroir products, the origin of an ingredient is generally considered less

\footnotetext{
109 These parameters have already been described in depth above. See, Sect. 5.2.

110 One of them is the specification of "Brioche Vandéenne PGI" that features a detailed list of all the ingredients and of the locations where they must be sourced, including those that must originate from the designated area. See, "Brioche Vandéenne PGI" C95/32 (13 March 2018).
} 
Table 11 Analysis of the sample of non-terroir agricultural GIs: overall results

\begin{tabular}{llcc}
\hline Parameters & Overall & Numbers & Percentage \\
\hline $\begin{array}{l}\text { Production } \\
\text { In the area }\end{array}$ & 75 & 61 & $81.3 \%$ \\
Raw materials & & & \\
Anywhere/NG & 75 & 68 & $90.6 \%$ \\
From the area & 75 & 7 & $9.3 \%$ \\
From specific area & 75 & 0 & \\
Link & & & \\
Nature & 75 & 8 & $10.6 \%$ \\
Human element & 75 & 70 & $93.3 \%$ \\
Traditional method & 75 & 53 & $70.6 \%$ \\
\hline
\end{tabular}

important than its organoleptic qualities. For instance, the Portuguese PGI "Folar de Valpaços" has to be produced using a specific PDO olive oil or any other oil having similar organoleptic qualities, thus indicating that, for the sake of the production, an origin product is as adequate as a generic one. ${ }^{111}$

Turning to the origin link, 70 specifications out of $75(93.3 \%)$ link the product to the designated area by making reference to the historical roots of the product and/or to the existence of traditional recipes. Also in this case the traditional character of the method of production is highlighted very often, specifically in more than the $70.6 \%$ of the cases. ${ }^{112}$

As to terroir, only 8 specifications out of 75 (approx. 10.6\%) mention the importance of natural/physical factors for the production of the goods and the impact of these elements on the characteristics of the end product. These results were foreseeable since the goods under analysis are not directly related to their local terroir.

\subsection{Observations on Part 3 of the Analysis}

Part 3 of the analysis has confirmed that non-terroir agricultural products and nonagricultural products or handcrafts have many elements in common. In particular, it is expedient to highlight that in both scenarios the origin of the raw materials is not considered crucial as the products are generally linked to their area of origin mainly through their reputation and through the fact that they are made following methods of production that are described as rooted in the designated area. In conclusion, the last two parts of the analysis show that protecting handcrafts through GIs, and in particular by applying EU Regulation 1151/2012 as a model, is a viable option. This last point will be better investigated below.

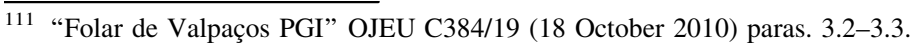

${ }^{112}$ For some examples of this kind of specifications, see "Pane casereccio di Genzano PGI" (EN/06/97/ 49830200.WOO (IT)); "Daujènunnaminèduona PGI" (LT/PGI/0005/01059) and "Pastel de Chaves PGI" (PT/PGI/0005/01126).
} 


\section{Assessment of the Suitability of the EU GI Quality Schemes to Be Extended to Non-Agricultural Products}

From the data presented in the previous sections, it is possible to proceed to an assessment of the suitability of the present EU sui generis GI system to be extended to non-agricultural products. The assessment will take into consideration the PDO and PGI quality schemes and it will add some observations on TSGs as well.

\subsection{Protected Designations of Origin}

In 2014, the relevant stakeholders were asked whether they were in favour of a dual system of protection characterised by two different links, one stronger than the other. ${ }^{113}$ In other words, the question was aimed at assessing whether the producers wanted to extend both EU GI quality schemes, PDOs and PGIs, to non-agricultural goods. The results were very polarised with $32.5 \%$ advocating in favour of a double type of link and $28.6 \%$ against it. Interestingly, $38.9 \%$ of the interviewed stakeholders stated they had no opinion on the matter.

In particular, those in favour of a system featuring both PDOs and PGIs maintained that this would have enhanced harmony between the existing EU sui generis GI systems. Furthermore, they argued that, considering the category of nonagricultural products is extremely broad, a double system would cover a higher variety of cases, thus being more flexible and able to provide more choices to the producers. ${ }^{114}$ By contrast, those in favour of the extension of PGIs only put forward three different arguments: (1) the system would be less complex and more understandable by consumers; (2) the majority of the products are not made from local raw materials, thus making the PDO quality scheme hardly applicable; and (3) the GI regimes of many non-EU states feature only GIs, without making any further distinction between different quality schemes. Hence, a system based only on PGIs would facilitate the international negotiations with third countries. ${ }^{115}$

The present article has shown that although the AOs are already used for protecting non-agricultural products, ${ }^{116}$ in the EU the PDO quality scheme would be applicable only in a few cases. Indeed, the empirical assessment has revealed that only in $13.1 \%$ of analysed cases must the products be made only from locally sourced raw materials, since often the producers are left free to choose between local and non-local raw materials. Interestingly, this almost coincides with the percentage of the products that feature the natural element of terroir, i.e. the physical/environmental link between the goods and their place of origin, which amounts to $14 \%$. These figures are in line with the fact that these are products based on know-how and their method of production and not on terroir, hence they are different from the typical PDO products. In conclusion, on the basis of the set of specifications analysed by the present article, the PDO model could be applicable to only to a limited number of products. Therefore,

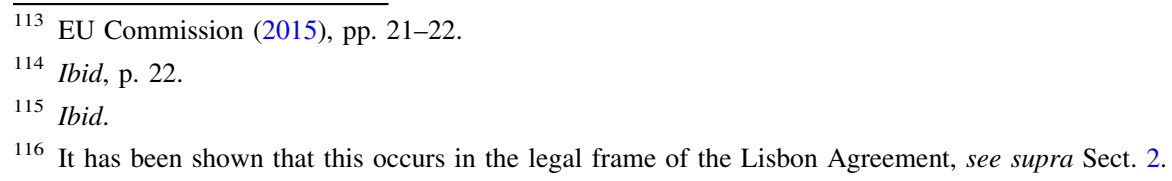


whether this quality scheme should be extended to the protection of non-agricultural products it is unclear and should be a matter of discussion at the EU level.

\subsection{Protected Geographical Indications}

The results of the empirical analysis carried out by this article shows that the PGI quality scheme may be the best legal tool to provide protection to non-agricultural products. Indeed, the research has demonstrated that there is a parallelism between this category of goods and non-terroir-related agricultural products that already enjoy GI protection in the EU, generally though PGIs. In particular, in both cases the raw materials are generally not sourced locally and the link consists in the reputation of the product, that often takes the form of the history of the good. ${ }^{117}$

Moreover, it has been shown that in the field of non-agricultural products, the "true" origin of a product is distinguished by its adherence to traditional practices codified in details by producers based within the designated area. The importance given to this element recalls the provisions on TSGs while PGI rules require only the evidence of a qualitative and/or reputational link, which at least formally does not overlap with the traditional character of the method of production. However, this paper has also shown that non-terroir agricultural products in approximately the $70 \%$ of cases feature references to the traditional character of the methods of production employed in the production of the goods. Indeed, also in this case the content of PGI specifications is hard to distinguish from that of a TSG. Two examples will demonstrate this statement. For instance, this is a substantial part of the link section of the specification of a PGI bakery product:

In the Municipality of Chaves, there is written and oral evidence attesting that "as far back as 1862 the Pastel was being produced in Chaves by the first pasteleira [...]." The tradition and know-how have been handed down until today and a clear sign of the product's link with the area is the name "Pastel de Chaves" and the fact that no similar products or even imitations are produced in neighbouring areas. For 150 years Chaves pastry makers have been building up knowledge of how to make the filling and the dough, which has resulted in this pastry, whose reputation is directly linked with its place of origin. $^{118}$

It can be observed that it is almost indistinguishable from this section that justifies the traditional character of a TSG good:

Pogača has a long tradition in Bela Krajina, being handed down from generation to generation, since it is a real specialty of the region. Housewives baking bread in the baker's oven for domestic use would always also bake pogača for the children so that they could eat it warm while the bread underwent the necessary cooling down before it could be eaten. Even nowadays it is still extremely typical, with housewives preparing it and

\footnotetext{
117 See supra p. 4.

118 "Pastel de Chaves PGI" (PT/PGI/0005/01126), supra para. 5.1.
} 
offering it to welcome guests they have invited to their home, but it is also offered to guests on farm stay holidays [...]. ${ }^{119}$

A discussion on the relationship between PGIs and TSGs would exceed the scope of the present article. However, the data presented above demonstrate that the former is already capable of accommodating the specifications of non-agricultural products predominantly based on the traditional character of its method of production. In this case, nevertheless, the specifications should also provide information on the history of the product or on its market reputation in order to prove at least its reputational link with a given geographical area.

In conclusion, the results of the analysis carried out by the present article suggest that the PGI model may be suitable to provide protection to non-agricultural GIs without the need of any specific adjustment since they would be able to encompass specifications based both on reputation and on the traditional character of the method of production.

\subsection{Traditional Specialities Guaranteed}

TSGs are not labels of origin. However, the present research has shown that a considerable number of specifications are based on the traditional character of the applied method of production rather than on the mere place of manufacturing. Indeed, the rationale for TSGs has been significantly absorbed by PGIs, as the data provided above show. Furthermore, the importance of the method of production has been explicitly recognised by the best practices available at the national level. The French law, as shown above, ${ }^{120}$ has already qualified this element as a viable link together with all the general ones that characterise PGIs, i.e. quality and reputation. Therefore, despite not being widely used, the rationale of TSGs is becoming increasingly important in practice in order to define origin products that cannot be linked to their area of origin by physical and/or natural elements.

\section{General Conclusions}

This article aims to contribute to the debate concerning the extension of the EU sui generis GI system to non-agricultural products. In particular, the work has conducted an assessment of the suitability of the existing quality schemes - PDOs and PGIs - to fulfil the task.

More specifically, this contribution, after having outlined the history of the debate on this issue in the EU, has carried out a research divided into three main parts, presented under Sects. 4, 5, 6, respectively. Part 1 has compared and contrasted the relevant national provisions of France, Portugal and Italy. It has concluded that France can be considered the "best practice" since it has adopted a specific sui generis GI for the protection of non-agricultural goods clearly based on the structure of Regulation 1151/2012 and, in particular, on the PGI quality scheme.

\footnotetext{
119 "Belokranjska pogača TSG" (EC No: SI-TSG-007-0029-29.10.2004), supra para. 3.8.

120 See supra Sect. 4.1.6.
} 
In addition, the analysis has revealed that all these different legislative approaches highlight the importance of the traditional character of the method of production employed as well as of the fact that the product must represent the history and the heritage of its area of origin.

This, and other relevant trends, have been confirmed by the empirical assessment conducted in Part 2 of the research, where the specifications of 112 non-agricultural products of different kinds have been analysed by applying a specific set of assessment criteria. In particular, the findings confirmed that the traditional character of the method of production is a crucial element of the nature of these goods, together with a reputational link that often consists in the history of the product and of its connection to the local heritage. Furthermore, it emerged that, although the majority of these goods are entirely produced within a well-determined geographical area, the specifications very often leave the producers free to source the raw materials from wherever they prefer. Indeed, this feature was also highlighted by the abovementioned comparative analysis.

Next, Part 3 of the research has analysed a sample of non-terroir agricultural products that appear on the EU GI register. Indeed, these goods have similar features in common with handcrafts. In particular, they are both linked to their place of origin prevalently, or exclusively, by human elements and are often made in accordance with a recipe that is defined as "traditional" and that sets them apart from similar non-origin goods. Interestingly, the analysis has shown that the key features of these products match those of the handcrafts analysed in Part 2 of the research, thus suggesting that the EU sui generis GI regime, and in particular the PGI quality scheme, may be already fit for being extended to the protection of these products. Lastly, the work has shown that, at least on the basis of the employed samples, the PGI quality scheme has in many ways absorbed TSGs and it is regularly used to protect goods characterised by a traditional method of production.

Finally, the work has concluded that, on the basis of the findings of the conducted comparative and empirical analyses, PDOs could be useful to protect only a limited number of non-agricultural products, while PGIs could be applied immediately and effectively to virtually all of them. Indeed, the public consultation promoted by the EU Commission in 2014, and completed in 2015, revealed that the stakeholders are divided on whether a sui generis GI system for the protection of non-agricultural products should feature both or just one of the two quality schemes. Hence, we believe that the results of the present assessment, although limited, could provide some guidance for EU policymakers to take a position of this delicate topic. As a final remark, we would like to stress, once again, that the design of an overall EU system for the protection of non-agricultural GIs also requires a discussion on broader policy issues, for instance, on how the overall institutional framework as a whole should be structured as well as an in-depth economic analysis. Nevertheless, these research topics would have exceeded the scope of the present investigation and, therefore, they have been left for further consideration.

Acknowledgements Open access funding provided by the Max Planck Society.

Open Access This article is distributed under the terms of the Creative Commons Attribution 4.0 International License (http://creativecommons.org/licenses/by/4.0/), which permits unrestricted use, 
distribution, and reproduction in any medium, provided you give appropriate credit to the original author(s) and the source, provide a link to the Creative Commons license, and indicate if changes were made.

\section{References}

\section{Books}

Blakeney M (2014) The protection of geographical indications: law and practice. Edward Elgar, Cheltenham

Gangjee D (2012) Relocating the law of geographical indications. Cambridge University Press, Cambridge

Le Goffic C (2010) La Protection Des Indications Géographiques. LexisNexis, New York

Mantrov V (2014) EU law on indications of geographical origin. Springer, Berlin

Marie-Vivien D (2012) La Protection Des Indications Géographiques: France, Europe, Inde. Éditions Quae, Versailles

Marie-Vivien D (2015) The protection of geographical indications in India: A new perspective on the French and European experience. Sage Law, Sunrise

Parker T (2015) Tasting French terroir: the history of an idea. University of California Press, Berkley Trubek AB (2008) The taste of place: A cultural journey into terroir. University of California Press, Berkeley

Wilson JE, Terroir (University of California Press; Wine Appreciation Guild 2012)

Ribeiro de Almeida RF (2008) IndicaçãoGeográfica, Indicação de Procedência e Denominação de Origem, vol 5. Direito Industrial, Almedina

\section{Contribution to edited works}

Allaire G, Casabianca F, Thévenod-Mottet E (2011) Geographical origin: a complex feature of agro-food products. In: Barham E, Sylvander B (eds) Labels of origin for food: local development, global recognition. CABI, Wallingford

Barham E (2016) Translating terroir revisited: the global challenge of French AOC labeling. In: Gangjee D (ed) Research handbook on intellectual property and geographical indications. Edward Elgar Pub, Cheltenham

Bérard L (2016) Terroir and the sense of place. In: Gangjee D (ed) Research handbook on intellectual property and geographical indications. Edward Elgar Pub, Cheltenham

Bérard L, Marchenay P (2004) Prouver l'Origine. In Bérard L and Marchenay P (eds) Les produits de terroir: entre cultures et règlements. CNRS Editions (Open Edition)

Gangjee D (2017a) From geography to history: geographical indications and the reputational link. In: Calboli I, Ng-Loy WL (eds) Geographical indications at the crossroads of trade, development, and culture in the Asia-Pacific. Cambridge University Press, Cambridge

Marie-Vivien D (2016) A comparative analysis of GIs for handicrafts. In: Gangjee D (ed) Research handbook on intellectual property and geographical indications. Edward Elgar Pub, Chelteham

\section{Journal Articles}

Bineau L (2013) Une Extension Attendue de l'indication Géographique Protégée Aux Produits Manufacturés Contrats, Concurrence, Consommation

Cordier G, Vilar D (2013) Les Indications Géographiques Dans Le Projet de Loi Relatif à La Consommation' Cahiers de droit de l'entreprise. Jurisclasseur

Das K (2010) Prospects and challenges of geographical indications in India. J World Intellect Prop 13:148

Gangjee D (2017b) Proving provenance? Geographical indications certification and its ambiguities.

World Dev 98:12 
Laferté G (2012) Regionalism in the marketing of French luxury goods: the example of Burgundy wines in the inter-War years. Centre d'Economie et Sociologie appliquées à l'Agriculture et aux Espaces Ruraux Working Paper 2012/2

Letablier MT, Nicolas F (1994) Genèse de La Typicité. Sci Aliments 14:541

Marie-Vivien D (2013a) La Protection de l'indication Géographique de Produits Industriels et Artisanaux: Le Choix d'un Régime Juridique Spécifique En Question. Contrats Concurrence Consommation

Marie-Vivien D (2013b) The protection of geographical indications for handicrafts or how to apply the concepts of natural and human factors to all products. WIPO J 4:191

Tosato A (2013) The protection of traditional foods in the EU: traditional specialities guaranteed. Eur Law J 19:545

Zappalaglio A (2018) The why of geographical indications: the transformation of the link between the product and its place of origin in Europe. University of Oxford, Oxford. https://ora.ox.ac.uk/objects/ uuid:d7124003-81b5-4d7b-8c27-eba29c8a3d24

Zappalaglio A (2019) The debate between the European Parliament and the Commission on the definition of protected designation of origin: why the parliament is right. Online IIC. https://link.springer.com/ article/10.1007/s40319-019-00797-x

\section{Reports, conference papers and other documents}

D'Avigneau VM, Mejer M (2018) Geographical indication (GI) protection for non-agricultural products in Europe'. Trademarks and geographical indications: future perspectives. EUIPO, Alicante. https:// euipo.europa.eu/knowledge/course/view.php?id=3342

EESC (2014) Opinion of the European Economic and Social Committee on the Green Paper, Making the most out of Europe's traditional know-how: a possible extension of geographical indication protection of the European Union to non-agricultural products

EU Commission (2014) Making the most out of Europe's traditional know-how: a possible extension of geographical indication protection of the European Union to non-agricultural products

EU Commission (2015) Results of the public consultation and public conference on the Green Paper Making the most out of Europe's traditional know-how: a possible extension of geographical indication protection of the European Union to non-agricultural products

European Commission (2011) A single market for intellectual property rights: boosting creativity and innovation to provide economic growth, high quality jobs and first class products and services in Europe

INPI, Base Indications Géographiques. https://www.inpi.fr/fr/comprendre-la-propriete-intellectuelle/lesindications-geographiques

Governo dos Açores, 'Artesanato dos Açores'. http://artesanato.azores.gov.pt

InSight REDD, OriGin (2013) Study on Geographical Indications Protection for Non-Agricultural Products in the Internal Market

WIPO, The International System of Appellation of Origin. https://www.wipo.int/lisbon/en

\section{Legislation}

Decree law (Decreto Lei) n. 121/2015

Decreto n. 30679, de 24-08-1940' (Diário da República n. 197/1940, Série I, de 10-12-2018)

India (1999) Geographical Indications of Goods (registration and protection) Act

Legge Regionale(Regione Abruzzo), 30 Ottobre 2009

Legge Regionale(Regione Basilicata) 12 Agosto 2015, n. 29

Legge Regionale (Regione Lazio) 17 Febbraio 2015

Legge Regionale (Regione Puglia) 5 Agosto 2013 n. 24

Legge Regionale (Regione Veneto) 8 Ottobre 2018 n. 34

Legge Regionale (Regione Veneto), 23 Dicembre 1994 n. 70 


\section{Specifications}

\section{France}

'Brioche Vandéenne PGI' C95/32 (13 March 2018)

'Porcelaine de Limoges' (INPI-1702, 1/01/2017)

'Pierre de Bourgogne' (INPI-1801, 29/06/2018)

'Tapisserie d'Aubusson' (INPI-1803, 07/12/2018)

\section{Italy}

Artigiani in Liguria, 'Marchio Artigiani in Liguria'. http://www.artigianiliguria.it/home.php?info= $1 \&$ idq $=1$

Biella Art of Excellence 'Disciplinare'. http://www.biellatheartofexcellence.com/it.html

Consorzio Liutai “Antonio Stradivari” Cremona, 'Cremona Liuteria - Allegato B'. http://www. cremonaviolins.com/il-consorzio/il-marchio-il-regolamento-la-tutela/

Consorzio Liutai Antonio Stradivari Cremona, Il marchio - il regolamento - la tutela. http://www. cremonaviolins.com/il-consorzio/il-marchio-il-regolamento-la-tutela/

'Disciplinare di Produzione della PietraOllaredella Valtellina e Valchiavenna'. http://www. marchiovaltellina.it/sites/default/files/mcg/DisciplinarePietraOllare.pdf

'Pane casereccio di Genzano PGI' (EN/06/97/49830200.WOO (IT)

'Tuscia Viterbese: Lavorazioni dell'Artigianato Artistico e Tradizionale - Allegato B'. http://www. tusciawelcome.it/gesFiles/Filez/1521562486K171446.pdf

\section{Portugal}

'Barro Negro de Vilar de Nantes' (Indicação Geográfica n. 146, 02/11/2011)

'Bordado de CasteloBranco' (Indicação Geográfica n. 505)

'Fechaduras de madeira da ilha do Corvo' (Portarian. ${ }^{\circ}$ 3/2019 de 21 de janeiro de 2019

'Folar de Valpaços PGI' OJEU C384/19 (18 October 2010)

'Lenços de Namorados do Minho' (Indicação Geográfica n. 164, 22/07/2010)

'Pastel de Chaves PGI' (PT/PGI/0005/01126)

'Viola Braguesa' (Indicação Geográfica n. 534)

\section{Lithuania}

Daujęụnaminėduona PGI' (LT/PGI/0005/01059)

\section{Slovenia}

'Belokranjskapogača TSG' (EC No: SI-TSG-007-0029-29.10.2004)

Publisher's Note Springer Nature remains neutral with regard to jurisdictional claims in published maps and institutional affiliations. 